\title{
Conducting Visitor Travel Surveys: A Transit Agency Perspective
}

\author{
Gregory L. Newmark \\ Center for Neighborhood Technology
}

\begin{abstract}
Visitors represent an important potential market for transit. Unfortunately, since visitors generally lack local phone numbers and residential addresses, they constitute a hard-tosurvey population, and relatively little is known about their travel behaviors and preferences. Transit agencies seeking to better understand and better serve this market will need to conduct a visitor travel survey. Surprisingly few visitor travel surveys have been undertaken, and none have been designed expressly to meet the needs of transit agencies. This research addresses this gap in the public transportation planning literature by identifying and exploring the key issues a transit agency needs to consider to carry out an effective visitor travel survey.
\end{abstract}

\section{Introduction}

Transit agencies intent on growing ridership need to identify new users. One commonly overlooked market, likely to be substantial in any region where transit infrastructure is also substantial, is visitors. For example, in 2011, Chicago welcomed 43.6 million visitors (Bergen 2012) who stayed an average of 2.41 days (D. K. Shifflet and Associates Ltd. 2012). If these visits were spread evenly throughout the year, on any given day there would be roughly 288,000 visitors in Chicago-more than the entire residential population of Toledo, Ohio $(287,208$ people in 2010$)$. Such numbers, on their own, would warrant a transit system.

Visitors may be a particularly prime market for transit for reasons theorized in Table 1. Unfortunately, there have been very few travel surveys of visitors to test these claims. There is a robust tradition of visitor surveys among economic development agencies, but these fail to detail local travel behaviors. (Table 2 presents the sample of such surveys reviewed for this research.) There is also a robust tradition of travel surveys among transportation planning agencies, but these rarely incorporate non-residents. There are a handful of surveys that expressly combine both traditions, as shown in Table 3, but no attempt has been made to systematically review them. Furthermore, all of these surveys were undertaken by metropolitan planning organizations (MPOs) seeking to improve their travel demand modeling, not transit agencies seeking to build transit ridership. The 
Portland Metro Visitor Travel Study is a slight exception. Although undertaken by the MPO to improve its modeling, that modeling was aimed to understand demand for new rail transit service in the region's core (Resource System Group 2010).

TABLE 1.

Visitors May be More Likely to Use Transit, Because ...

\begin{tabular}{|c|c|}
\hline 1 & $\begin{array}{l}\text { Visitors often travel to a region via a non-automobile mode (e.g., plane, train, ship, or bus) } \\
\text { and, consequently, do not have a car at their immediate disposal. }\end{array}$ \\
\hline 2 & $\begin{array}{l}\text { Visitors often come from places, particularly abroad, with extensive transit networks and, } \\
\text { consequently, consider public transportation as a realistic travel option., }\end{array}$ \\
\hline 3 & $\begin{array}{l}\text { Visitors are likely to have specific trip destinations (e.g., downtown business districts, sport } \\
\text { stadiums, theaters, museums, nightlife venues) that are competitively served by transit. }\end{array}$ \\
\hline 4 & $\begin{array}{l}\text { Visitors may favor downtown lodging locations for the proximity to amenities. Such locations } \\
\text { typically have good transit access (as well as steep parking costs). }\end{array}$ \\
\hline 5 & $\begin{array}{l}\text { Visitors for non-business purposes may have relatively flexible time budgets and be more } \\
\text { amenable to comparatively longer travel times on transit. }\end{array}$ \\
\hline 6 & $\begin{array}{l}\text { Visitors who travel to a region by automobile (or who could rent one upon arrival) may prefer } \\
\text { not to drive in an unfamiliar city and will use transit for some local trips. }\end{array}$ \\
\hline 7 & $\begin{array}{l}\text { Visitors, particularly from abroad, may be less likely to have an appropriate driver's license } \\
\text { and would, therefore, not be able to borrow or rent a car. }\end{array}$ \\
\hline 8 & $\begin{array}{l}\text { Visitors may find transit offers faster or more reliable access from entry terminals, such as } \\
\text { airports, seaports, or train stations, to local destinations than cars do during daytime hours. }\end{array}$ \\
\hline 9 & Visitors are more willing to experience novelty, including using transit, in a new setting. \\
\hline 10 & Visitors on tight budgets view transit as a lower cost transportation option. \\
\hline 11 & $\begin{array}{l}\text { Visitors are unable to rely on habitual patterns for travel decisionmaking and might, } \\
\text { therefore, include transit in their transportation choice set. }\end{array}$ \\
\hline
\end{tabular}

Note: These are theories postulated by the author. 
TABLE 2.

Sample of Visitor Surveys

(Not Focused on Travel

Behavior)

\begin{tabular}{|c|c|c|c|c|c|}
\hline Year & Region & Season & Survey Methodology & Responses & Reference \\
\hline 2006 & Canada & Full Year & $\begin{array}{l}\text { Computer-assisted telephone } \\
\text { interview (CATI) administered by } \\
\text { government surveying agency. }\end{array}$ & 167,474 & $\begin{array}{c}\text { Statistics } \\
\text { Canada } 2006\end{array}$ \\
\hline 2007 & Portland, OR & Full Year & $\begin{array}{l}\text { Self-administered paper surveys } \\
\text { mailed by the private surveying } \\
\text { company to its panel of } \\
\text { respondents. }\end{array}$ & 776 & $\begin{array}{l}\text { Longwoods } \\
\text { International } \\
2007\end{array}$ \\
\hline 2009 & Flagstaff, AZ & Full Year & $\begin{array}{l}\text { Self-administered paper survey } \\
\text { distributed by staff at the five } \\
\text { surveying locations-no special } \\
\text { surveyors. }\end{array}$ & 1,068 & $\begin{array}{c}\text { Arizona } \\
\text { Hospitality } \\
\text { Research \& } \\
\text { Resource Center } \\
2009\end{array}$ \\
\hline 2010 & London, UK & Jan-Sept & $\begin{array}{l}\text { Face-to-face interviews } \\
\text { conducted by professional } \\
\text { surveyors who intercept visitors } \\
\text { throughout the region. }\end{array}$ & 4,020 & $\begin{array}{l}\text { TNS Travel and } \\
\text { Tourism } 2010\end{array}$ \\
\hline 2012 & Cardiff, UK & Summer & $\begin{array}{l}\text { Face-to-face interviews } \\
\text { conducted by professional } \\
\text { surveyors who intercept visitors } \\
\text { at five locations. }\end{array}$ & 1,282 & $\begin{array}{l}\text { Cardiff Research } \\
\text { Center } 2010\end{array}$ \\
\hline 2012 & USA & Full Year & $\begin{array}{l}\text { Self-administered paper survey } \\
\text { distributed either on-board } \\
\text { international flights from U.S. } \\
\text { or at departure gates for those } \\
\text { flights. Distribution is either } \\
\text { conducted by airline staff or } \\
\text { professional surveyors. }\end{array}$ & $\sim 40,000$ & $\begin{array}{l}\text { International } \\
\text { Trade } \\
\text { Administration } \\
2012\end{array}$ \\
\hline 2012 & UK & Full Year & $\begin{array}{l}\text { Face-to-face interviews } \\
\text { conducted by professional } \\
\text { surveyors who intercept visitors } \\
\text { leaving UK by air, sea, and tunnel } \\
\text { routes. }\end{array}$ & $\sim 300,000$ & $\begin{array}{c}\text { Office for } \\
\text { National } \\
\text { Statistics } 2012\end{array}$ \\
\hline 2012 & $\begin{array}{c}\text { Minneapolis, } \\
\text { MN }\end{array}$ & Summer & $\begin{array}{l}\text { Face-to-face interviews } \\
\text { conducted by professional } \\
\text { surveyors who intercept visitors } \\
\text { at } 34 \text { sites throughout region. }\end{array}$ & 1,294 & $\begin{array}{c}\text { Oftedal and } \\
\text { Schneider } 2012\end{array}$ \\
\hline 2012 & Australia & Full Year & $\begin{array}{l}\text { Computer-assisted telephone } \\
\text { interview (CATI) administered by } \\
\text { government surveying agency. }\end{array}$ & $\sim 120,000$ & $\begin{array}{c}\text { Tourism } \\
\text { Research } \\
\text { Australia } 2012\end{array}$ \\
\hline
\end{tabular}

Note: The Portland survey represents those respondents to Longwoods International's 2004 and 2006 Travel USA survey that reported visiting metropolitan Portland; the full sample of the Travel USA survey is much larger. 
TABLE 3.

Examples of Visitor Travel

Surveys

\begin{tabular}{|c|c|c|c|c|c|c|}
\hline Year & Region & Season & Intercept Location Types & $\begin{array}{l}\text { Intercept } \\
\text { Sites }\end{array}$ & Responses & Reference \\
\hline 2000 & $\begin{array}{l}\text { Southeast } \\
\text { Florida }\end{array}$ & Winter & Hotels, motels & 78 & 1,063 & $\begin{array}{l}\text { Carr Smith } \\
\text { Corradino } \\
2000\end{array}$ \\
\hline 2004 & $\begin{array}{l}\text { Lake } \\
\text { Tahoe }\end{array}$ & Summer & $\begin{array}{l}\text { Hotels, casinos, resorts, other } \\
\text { activity centers }\end{array}$ & 15 & 798 & NuStats 2004 \\
\hline 2008 & $\begin{array}{l}\text { San } \\
\text { Antonio, } \\
\text { TX }\end{array}$ & Summer & $\begin{array}{l}\text { Hotels, motels, downtown } \\
\text { malls, historic sites, tourist } \\
\text { attractions, amusement parks }\end{array}$ & 16 & 621 & $\begin{array}{c}\text { ETC Institute } \\
2008\end{array}$ \\
\hline 2009 & $\begin{array}{l}\text { US Virgin } \\
\text { Islands }\end{array}$ & Winter & Airport, cruise boarding areas & NA & $\sim 900$ & Simek 2009 \\
\hline 2010 & $\begin{array}{l}\text { Portland, } \\
\text { OR }\end{array}$ & Winter & $\begin{array}{l}\text { Convention center, library, } \\
\text { airport, downtown mall, civic } \\
\text { sites }\end{array}$ & 9 & 196 & $\begin{array}{l}\text { Resource } \\
\text { System } \\
\text { Group } 2010\end{array}$ \\
\hline 2012 & $\begin{array}{c}\text { San Diego } \\
\text { CA }\end{array}$ & Summer & Airport, hotels & 101 & 1,174 & $\begin{array}{c}\text { SANDAG } \\
\text { Applied } \\
\text { Research } \\
\text { Division } 2012\end{array}$ \\
\hline 2013 & Oahu, HI & Fall & Airport & 1 & 846 & $\begin{array}{c}\text { McCutchan } \\
2013\end{array}$ \\
\hline
\end{tabular}

Note: Other than the Portland survey, all visitor travel surveys were based entirely on face-to-face intercept interviews. The Portland survey used a mix of methods to reach visitors. The nine intercept locations represent computer-aided interviews aimed at both visitors and residents. The survey software asked a screener question that delivered the appropriate survey instrument. In total, 77 visitor responses were captured by this method. In addition, postcards were handed out at hotels, transit stations, and the airport to invite visitors to go online to participate in the survey; residents who participated in the household survey and volunteered their email addresses to be contacted for future surveys were emailed a link to the visitor survey to forward to anyone they might know who had recently visited the region. The monthly electronic newsletter for people who had signed up at TravelPortland.com also included the survey link for two months during the survey period.

Transit agencies need guidance to conduct a visitor travel survey. This research examines existing survey efforts to explore the issues involved in designing and administering a visitor travel survey. This research first identifies the appropriate policy objectives driving a visitor travel survey and then asks the key questions that undergird any such survey effort: Who is a visitor? Where can visitors be intercepted? What should visitors be asked? How can a visitor travel survey be administered?

\section{Policy Objectives}

Since surveying is costly, it is important to be clear on the ultimate use of the data collected. This research holds that transit agencies conduct visitor travel surveys to inform policies for growing ridership and revenue from visitors. Typically, agencies are interested in filling spare capacity on existing services and identifying any new services or fare programs that would cater to the visitor market.

The survey should yield sufficient information to determine if the visitor demand warrants any policy change. Specifically, the survey needs to characterize and quantify visitor submarkets that are amenable to using transit, identify existing barriers to additional 
transit use, and estimate submarket reaction to changes in transit policy or infrastructure aimed at overcoming these impediments. This last task often will require the survey to assess visitor price sensitivity to different fare levels and products.

\section{Who is a Visitor?}

The first step to constructing an appropriate visitor travel survey is to define a visitor. Table 4 presents several definitions from recent surveys. These are based on a combination of spatial, temporal, and trip purpose characteristics.

TABLE 4. Who is a Visitor? A Sampler of Survey Definitions

\begin{tabular}{|c|c|}
\hline Survey, Location (Source) & Visitor Definition \\
\hline $\begin{array}{l}\text { Visitor Travel Survey, Southeast } \\
\text { Florida (Carr Smith Corradino 2000) }\end{array}$ & All hotel or motel guests are considered visitors. \\
\hline $\begin{array}{l}\text { Summer Visitors Travel Survey, Lake } \\
\text { Tahoe (NuStats 2004) }\end{array}$ & Visitors are defined as people whose home ZIP codes are outside those of the Lake Tahoe region. \\
\hline $\begin{array}{l}\text { Canadian Travel Survey: Domestic } \\
\text { Travel, 2004, Canada (Statistics } \\
\text { Canada 2006) }\end{array}$ & $\begin{array}{l}\text { "Trip. For the purposes of the CTS, a trip is defined as travel to a Canadian destination at least } 80 \mathrm{~km} \\
\text { one-way from home for any reason except: travel to and from work or school (i.e., commuting); one- } \\
\text { way travel involving a change of residence; travel of operating crew members of buses, airplanes, boats, } \\
\text { etc.; travel in an ambulance to a hospital or clinic; trips that did not originate in Canada; trips longer } \\
\text { than a year. ... Traveler. Anyone who takes a trip." }\end{array}$ \\
\hline $\begin{array}{l}\text { US Travel Association TIEM model, } \\
\text { Illinois (U.S. Travel Association } \\
\text { 2009) }\end{array}$ & $\begin{array}{l}\text { U.S. residents traveling in Illinois includes both state residents and out-of-state visitors traveling away } \\
\text { from home overnight in paid accommodations, or on day or overnight trips to places } 50 \text { miles or more } \\
\text { away from home. Travel commuting to and from work; travel by those operating an airplane, bus, truck, } \\
\text { train or other form of common carrier transportation; military travel on active duty; and travel by } \\
\text { students away at school are all excluded from the model. }\end{array}$ \\
\hline $\begin{array}{l}\text { Portland Metro Visitor Travel } \\
\text { Survey, Portland (Resource System } \\
\text { Group 2010) }\end{array}$ & Visitors self-identify based on their response to the question: "Are you a visitor to the Portland area?" \\
\hline $\begin{array}{l}\text { London Visitor Survey, London } \\
\text { (TNS Travel and Tourism 2010) }\end{array}$ & $\begin{array}{l}\text { "The London Visitor Survey is conducted among the following visitor types: Overseas visitors; UK } \\
\text { staying visitors (UK residents who live outside Greater London and are staying at least one night in the } \\
\text { capital); Day visitors (those on trips of } 3 \text { hrs + not taken on a regular basis), including UK day visitors (UK } \\
\text { residents who live outside Greater London and are not staying overnight) [and] London residents (live } \\
\text { in one of the } 33 \text { London boroughs)." }\end{array}$ \\
\hline $\begin{array}{l}2012 \text { Metropolitan Area Visitor } \\
\text { Survey, Minneapolis/St. Paul } \\
\text { (Oftedal and Schneider 2012) }\end{array}$ & $\begin{array}{l}\text { "[A]nyone who stayed one to } 30 \text { nights or who was on a day trip in an area at least } 50 \text { miles from the } \\
\text { primary residence. Only leisure-related travelers were included; business and medical travelers were } \\
\text { excluded." }\end{array}$ \\
\hline $\begin{array}{l}\text { Cardiff Visitor Survey 2012, Cardiff } \\
\text { (Future Focus Research 2012) }\end{array}$ & $\begin{array}{l}\text { People who neither live nor work in the Cardiff Council Area and spent at least three hours in Cardiff } \\
\text { unless for a routine visit or appointment (e.g., visit to dentist, doctor, hairdresser, weekly shopping, etc.). }\end{array}$ \\
\hline $\begin{array}{l}\text { Oahu Visitor Survey, Honolulu } \\
\text { (McCutchan 2013) }\end{array}$ & $\begin{array}{l}\text { "Visitors were defined as a person at least } 16 \text { years of age that is from the Continental United States or } \\
\text { another country." }\end{array}$ \\
\hline
\end{tabular}


Spatial characteristics identify whether a respondent is physically distant from his or her home location. Surveys use two techniques for making this assessment: a cordon approach and a distance-from-home approach.

The cordon approach circumscribes a geographic boundary around a region and identifies non-residents found within that cordon as visitors. The Cardiff Visitor Survey, for example, has surveyors screen potential respondents by asking, "Do you live in the Cardiff area? By Cardiff I mean the Cardiff Council Area" (Future Focus Research 2012). Here, a known geo-political jurisdiction, the Cardiff Council Area, establishes the cordon of interest within which non-residents are considered visitors. This approach works well for identifying visitors within a region, particularly if the boundaries of that region are both clearly defined and relevant to a determination of visitor status. This approach works less well if the boundaries are not widely known, comprise too small an area (e.g., the District of Columbia or the City of San Francisco) and are therefore likely to pick up many regional residents, or the intercept point is too near the cordon line.

The distance-from-home approach somewhat addresses these shortfalls. This approach determines visitor status based on the straight-line distance, typically 50 miles (see Oftedal and Schneider 2012; Statistics Canada 2006; U.S. Travel Association 2009) from a home location. This approach is not affected by issues of jurisdictional boundaries, but it does suffer from some arbitrariness regarding the appropriate distance, as habitual travel distances do vary among regions. The distance-from-home approach is commonly used in household surveys aimed at understanding visitor behaviors elsewhere. Such surveys ask respondents to report on all travel that exceeds the distance threshold.

The two spatial approaches are converses. The cordon approach buffers an activity location and considers people with residential locations beyond that buffer as visitors; the distance-from-home approach buffers a residential location and considers people active beyond that buffer as visitors. From a transit agency perspective, the cordon approach is often more suitable, as it can better match visitors to a transit service area; however, the data gathered from household surveys through the distance-from-home approach can be very useful for structuring a visitor travel survey to a specific region.

Temporal characteristics, namely the duration of stay, can also be used to identify visitors. One approach is to set a minimum duration necessary to be considered a visitor. The Cardiff Visitor Survey, noted above, augments its spatial requirements with a temporal one that screens out non-residents who spend fewer than three hours in the Cardiff region (Future Focus Research 2012). Another, and often complementary, approach is to exclude people who exceed a given stay duration and are therefore thought to be more akin to full-time residents. The Twin Cities Metropolitan Area Visitor Survey screens out people spending more than 30 nights in the region (Oftedal and Schneider 2012). Temporal characteristics can also be used to segment the visitor market to capture distinct traveler behaviors. Both the U.S. Virgin Islands Visitor Survey and the Tahoe Summer Visitors Travel Survey offer separate survey instruments for visitors staying less than one day and those staying between 1 and 30 days (Simek 2009; NuStats 2004). This bifurcation can be useful for regions catering to a high number of day-trippers. 
Finally, the trip purpose can be used to confer visitor status. For example, in addition to spatial and temporal parameters, the Cardiff Visitor Survey also screens out commuters, people making routine non-work trips (e.g., weekly shopping), and people coming for appointments (e.g., seeing a hairdresser or dentist) (Future Focus Research 2012). The Twin Cities Metropolitan Area Visitor Survey excludes business and medical travelers to focus on the leisure market (Oftedal and Schneider 2012). Several surveys even consider residents as visitors if their trip purposes are for non-routine activities. The London Visitor Survey considers resident trips lasting more than three hours that are "not taken on a regular basis" as visiting trips (TNS Travel and Tourism 2010), the Australian National Visitor Survey considers "those who travel for a round trip distance of at least 50 kilometers [and] are away from home for at least four hours as visitors as long as the travel is not routine" (Tourism Research Australia 2012), and the US Travel Association considers anyone staying overnight in paid accommodation "regardless of distance away from home" a visitor (U.S. Travel Association 2009). This last approach is commonly used for surveys at hotels and motels (e.g., Carr Smith Corradino 2000; Tierney et al. 2013).

For most transit agencies, visitor status can be sufficiently conferred by spatial characteristics refined by trip purpose characteristics to remove extreme commuters. Temporal characteristics are likely superfluous unless that region has a unique visitor market to be targeted, such as seasonal "snowbirds" in Florida or cruise passengers on single-day port excursions in the Virgin Islands. However, in some cases, transit agencies may consider relaxing the spatial requirement for residents making non-routine trips. For example, a large metropolitan region with core-focused rail resources and sprawling car-oriented suburbs might be interested in the travel of residents who typically drive everywhere but will consider using transit to access special events in the central city. From the perspective of the transit agency, such occasional riders might be considered "visitors."

Transit agencies must decide whether to exclude or include these residents in a visitor travel survey. The argument for exclusion is that local residents represent a fundamentally distinct market from visitors. Residents have local knowledge, local addresses, established local travel habits, and often access to a local vehicle. Furthermore, the travel behaviors of this community (although probably not their preferences) have already been captured in household travel surveys administered by regional planning agencies. Therefore, incorporating this population unnecessarily adulterates a focused study on visitors from outside the region.

The argument for inclusion is that residents making non-routine trips are acting like visitors who need to actively consider their travel options for the unaccustomed journey (and consequently may be more amenable to transit). To the extent that these non-routine trip purposes are similar to those attracting visitor travel, such as attending a downtown sporting event or concert, any associated travel might also be well-served by transit interventions aimed at visitors. Additionally, as a practical matter, a visitor travel survey may afford a unique opportunity to capture the non-routine travel to transit-served venues as any interception will likely pick up many residents anyway. Inclusion of "local" visitors likely will require a second surveying instrument, which adds complexity to the survey effort. Chicago's regional transit planning agency is pursuing this inclusive approach 
of incorporating residents making certain non-routine trips within its upcoming visitor travel survey effort (Regional Transportation Authority 2014).

\section{Where Can Visitors Be Intercepted?}

Visitors lack both local addresses and landline telephones and, consequently, constitute a hard-to-sample population by traditional list-assisted surveying methods. National surveys sidestep this problem by sampling people at home locations and asking about their visits elsewhere over a recent time period, such as the last three months (e.g., Statistics Canada 2006; D.K. Shifflet and Associates Ltd. 2012; Longwoods International 2007; Tourism Research Australia 2012). This approach, while reasonable for tracking long-distance travel nationwide, is unlikely to yield sufficient visitors to a local transit agency's service area to enable statistically-significant data analysis. For example, the American Public Transportation Association (APTA) annual nationwide survey of prospective summer travel captured only 23 respondents out of 1,003 who intended to visit Chicago in 2013 (TechnoMetrica 2013). Furthermore, the reliance on recall from visits weeks or months earlier is unlikely to produce sufficient detail about local travel behaviors within the area of interest. A more realistic approach for transit agencies is to intercept visitors while in the region.

Such interception can be either physical or virtual. Physical interception refers to cases in which a visitor is approached in person by the surveyor (or an authorized proxy, such as a hotel clerk, toll collector, venue ticket taker, etc.) within or on the periphery of the study area. Virtual interception refers to cases in which a visitor is approached without any face-to-face contact, for example via email invitation, based on reasonable evidence that the respondent is (or has been) a visitor to the study area.

\section{Physical Interception}

Visitors can be physically intercepted since they share characteristics that both classify and locate them. These traits include the need to enter/exit the region, the activity purposes motivating the trip, and, for overnight visits, a need for lodging.

All visitors enter and exit a region. The long distance transportation network structures these movements and often funnels visitors through a limited number of access/egress points, including airports, seaports, train stations, bus terminals, bridges, highways, etc. Facilities that require visitors to transfer between long distance and local travel modes, such as airports, provide a particularly convenient opportunity for intercepting visitors, but typically are used by only a fraction of the total visitor population.

The absolute numbers of visitors arriving and departing by a given mode (as well as the relative shares) can be gleaned from the national surveys noted above. (Modally-specific databases, such as those kept on airline travel, can augment these data.) This information is essential for properly designing the sampling approach and for weighting and expanding the findings to the full visitor population. For example, Canada conducts a nationwide survey of domestic travel. The 2004 survey (Statistics Canada 2006) noted that, of the roughly 14,028,000 domestic visitors to the Toronto Metropolitan Area, 85 percent arrive by automobile, 9 percent by airplane, 3 percent by bus, and another 3 percent by rail. These numbers show that intercepting potential respondents at easy-to-survey terminals 
captures only 15 percent of the domestic visitor market and that a more complete analysis will require surveying visitors who come by private vehicle. (Transit agencies should not hesitate to spend resources surveying visitors who arrive by car since the goal of such an effort is to understand the extent to which these visitors remain amenable to using transit within the region.) Once again, national travel surveys can help guide this sampling as the included visitors' home locations can be used to infer visitor access flows on major highways. For example, in Toronto, visitors driving in from the east are likely to arrive via Highway 401, while visitors from the west are likely to arrive via Highway 400 . While physically intercepting drivers is challenging in the absence of a fully-manned toll plaza, this knowledge can still structure survey design. For example, a surveying station could be set up at specified rest stops, exit ramps, or visitor information centers with the national data helping to properly weight the resulting sample.

All visitors come to a region to engage in activities. Certain activities that gather large numbers of people in a single venue, such as attendance at a convention, concert, or sporting event, provide easy opportunities to physically intercept visitors. Local tourism bureaus typically track and publish counts of activity participation (e.g., City of Chicago 2010), which can facilitate visitor travel survey design and data expansion. Since cultural events attract distinct demographic groups-Chicago's famous music events Lollapalooza and the Chicago Blues Festival take place in the same venue but cater to distinct fan bases-special care must be taken in survey design, weighting, and data expansion to minimize the potential of a single event skewing the survey results. Transit agencies have particular interest in major events as these often are well-served by transit and offer excellent opportunities for cross promotion, such as by having event tickets double as short-term transit passes.

Many, but not all (and not necessarily the majority of) visitors to a region will require lodging. Again, national surveys provide breakdowns of overnight visitors versus day-trippers. The Canadian Travel Survey (Statistics Canada 2006) reports that 44 percent of domestic visitors to the Toronto Metropolitan region stay overnight. Overnight visitors can either stay in free or paid accommodation. The Canadian Travel Survey reports that 59 percent of domestic overnight visitors to Toronto stayed with friends or relatives, presumably for free. The 41 percent of domestic overnight visitors who pay for lodging may select public group accommodations (e.g., hotels, motels, and hostels), private group accommodations (e.g., dormitories, army barracks, clubs, etc.), or short-term property rentals, including new contracted couch-surfing services, such as Air-BnB. The Canadian data report that, in Toronto, 93 percent of domestic overnight visitors who pay for lodging use hotels and motels, while 7 percent use other accommodations. In combination, these numbers challenge the common assumption that surveys at hotels and motels are sufficient to capture the visitor market as only 17 percent of domestic visitors to Toronto use such lodging.

In general, the physical interception of visitors can occur in any place except their household location. Transit agencies have significant capacity for such interceptions having long conducted on-board surveys as well as surveys at the attraction end of a trip. The latter category includes small establishment surveys, such as restaurants or offices, and large special generators, such as airports, universities, and shopping malls. Since many of these surveys are likely to include responses from visitors, transit agencies are encouraged to 
review their existing stockpile of physical intercept efforts to inform design of a visitor travel survey.

\section{Virtual Interception}

Virtual interception is analogous to physical interception as visitors are contacted based on the same specific traits, such as access mode, activity participation, and lodging; however, virtual interception may be particularly useful for sampling visitors. Virtual interception can be less expensive than physical interception and therefore can reach a larger sample for the same cost and consequently better represent the travel behaviors of the full visitor population. Virtual interception can also provide a means to target respondent traits that are not conducive to physical interception, such as visitors who arrive by private vehicle.

Virtual interception of visitors entering or exiting a region could happen in a number of ways. Surveyors may partner with online travel agencies, airlines, ferry companies, intercity train or bus operators, consulates, or any organization that collects the contact information of non-residents who register to be in the study area during the study period. Such interception is very valuable as it often identifies visitors before their actual visit to the region and, in offering that advance contact, enables more specialized surveying possibilities (e.g., inviting participants to carry a GPS device, before-and-after surveying, survey participation reminders, commitment to completing trip diaries, etc.)

As noted above, virtual interception may provide an effective way to approach visitors entering the region by automobile. License plate recording devices placed at entering and exiting highways could identify passenger vehicles registered elsewhere that enter the region, but that do not exit it within a set period (to exclude through travelers); surveys could then be sent to owners of those vehicles (see Hourdos and Titzow 2011). Owners of interoperable highway toll transponders, such as EZ-Pass, with out-of-region billing addresses could be contacted after their transponder is read by local tolling machines. Both approaches address the challenge of intercepting the many visitors who arrive by highway without forcing them to stop driving. (Both approaches also require multiagency coordination and raise serious privacy concerns.)

Similarly, visitors who participate in activities that require advance registration or purchase might be contacted based on an out-of-region home or billing address. For example, coordination with event organizers, sports teams, theater owners, tourist attractions, etc., could yield a sample of visitors planning to come to the region. The same approach could be used to gather the contact information of visitors booking paid accommodation through hotel chains or online travel brokers. Since such registration now almost universally includes providing an email address, the cost of pushing surveys to respondents can drop dramatically.

Finally, the increasing ubiquity of geocoded data might present alternative methods of virtual interception. Surveys might be pushed to non-residents who "check in" to locations within the study area on services such as Facebook or Foursquare, to people who purchase in-room Internet service at hotels in the region, to cell phones operating within the region that have a payment address elsewhere, to computers that sign into local Internet protocol addresses that are distinct from their typical sign in addresses, etc. These 
methods of virtual interception are much more invasive and raise distinct privacy issues; nonetheless, it is important to consider the range of possibilities for reaching people that are by definition hard-to-reach.

\section{Survey Weighting}

Regardless of the interception approach, it is critical to properly weight the resultant sample to best represent the population of inference. Too often, surveys intercept visitors at hotels and airports only and then suggest that those findings hold for all visitors to a region. There are certainly cases, such as for air passengers leaving the island of Oahu (McCutchan 2013), where this assumption is quite reasonable; however, for most metropolitan areas, visitors are most likely to come by car and to not pay for lodging. Good survey practice identifies a weighting scheme that accounts for several visitor traits. (Such schemes also facilitate choice-based sampling, which can reduce the needed number of respondents.)

As noted above, national travel surveys are particularly useful for helping to inform this process. Private companies (e.g., Longwoods International, D. K. Shifflet \& Associates Ltd., TNS) conduct nationwide surveys on travel and sell the data to convention and visitor bureaus. National governments collect data on travel behavior (e.g., in the U.S. through the National Household Travel Survey and the Survey of International Air Travelers). Transit on-board survey results also can help with expansion as they often ask for home location ZIP code, which could be used to estimate visitors-as long as visitors were encouraged to complete them. A private company, AirSage (www.airsage.com), has begun selling data on the triangulated locations of mobile devices in contact with cell towers. The company's data-processing algorithms attempt to identify home and work locations for devices, which can then be used to identify visitors to a region. AirSage offers these location data in origin and destination tables at any level of geography for any time period.

\section{Targeting Potential Transit Riders}

Transit agencies need not capture the entire visitor population in a visitor travel survey; rather, they might focus on those portions of the visitor population that could realistically use existing or planned transit systems, i.e., those visitors whose trips have origins and destinations competitively connected by current or proposed transit services. Targeting such visitors can be challenging in practice. One approach is to limit interception to areas that are well-served by transit; this guarantees that at least one trip end is transit-accessible. The survey design might further screen out respondents based on their other reported trip ends. Here, the AirSage data may be particularly helpful as they identify visitor flows, which can be used to both identify good interception points and appropriately weight the data collected.

\section{What Should Visitors Be Asked?}

Once the sample frame has been identified and intercepted, it is important to know what to ask. Visitor travel surveys alter traditional components of travel surveys (i.e., sections on travel and activity behaviors, stated preferences and customer satisfaction, and 
socio-demographics) with the focus on visitors. Furthermore, visitor travel surveys add a new section about the visit itself.

\section{Travel and Activity Behaviors}

Visitor travel and activity behaviors are distinct from those of residents. Visitors use a different mix of travel modes, participate in a different mix of activities, and travel to a different mix of places. Furthermore, visitors are likely to vary each of these elements more on a day-to-day basis than residents. An effective visitor travel survey will provide sufficient detail to identify a potential transit opportunity and enable nuanced statistical analysis.

Visitors disproportionately use modes that are too marginal to be broken out in a resident travel survey. These modes need to be distinguished to understand visitor travel; consequently, the Oahu Visitor Survey offers taxi/limo, rental car, hotel shuttle, and chartered sightseeing/tour bus as modal options and finds these four modes account for 47 percent of visitor trips (McCutchan 2013). The San Antonio Regional Visitor Survey includes other non-standard modes catering to tourists, including river barge, horse carriage, and pedicab (ETC Institute 2008). Regions investing in cycling infrastructure might include biking (and distinguish bike-sharing, bike-rental, and bike-borrowing) as a complement to transit use. Similarly, transit agencies should provide heightened modal specificity on their services. For example, while the household travel survey for the San Francisco Bay Area clusters all rail services operated by the city as San Francisco Muni-Train (Morpace International, Inc. 2000), a visitor travel survey might distinguish between light rail, historic streetcar, and cable car services, as the latter two are disproportionately ridden by visitors.

Visitors engage in a distinct set of activities from residents. By the very nature of being away from their home locations, visitors are unlikely to conduct household maintenance activities such as grocery shopping or escorting children to school; instead, they are more likely to engage in discretionary activities, such as eating in restaurants or sightseeing. Visitor travel surveys need to provide additional detail in these areas. Accordingly, the Oahu Visitor Survey includes trip purposes such as freshen up/drop off things, beach, and other recreation/sightseeing unlikely to be included on a traditional travel survey (McCutchan 2013).

These distinct activities also take place at distinct venues. Visitors are much more likely to find themselves in hotels, tourist attractions, sports stadiums, convention centers, and performance spaces than residents. It is, therefore, not unreasonable to identify such common locations by name in a visitor travel survey. The 2012 Cardiff Visitor Survey asks specifically if visitors visited or intended to visit 28 different named attractions while in the region (Future Focus Research 2012). The San Antonio Regional Visitor Survey offers destination codes for 14 named attractions (ETC Institute 2008). Such destination specificity facilitates visitors' recall while speeding (and improving the accuracy of) survey coding. Such specificity also may enable transit agencies to ask additional questions of respondents visiting destinations of interest, as is discussed below.

Visitors are also more likely to vary their travel and activity behaviors than residents. This propensity may complicate visitor travel surveys. Ideally, visitors would record all of their travel and activity behaviors from when they entered the region until they left it; however, ensuring such comprehensiveness is doubtful (although the next section offers 
some promising ideas). The question then arises of what is the appropriate time frame for reporting travel and activity behaviors? Surveys generally take two approaches. The first is to consider an entire trip, but without a detailed breakdown of travel. This approach is common among traditional visitor surveys, which do not focus on local travel. For example, the London Visitor Survey asks respondents to identify all the travel modes used and all the places already visited or intended to visit while on their excursion in London (TNS Travel and Tourism 2010). The second approach is to consider a shorter time period, but with a detailed breakdown of travel. All the visitor travel surveys in Table 3 used this approach and requested trip information similar to a standard household travel survey for the full day prior to surveying.

Requesting trip diaries for the day prior to surveying is problematic as many overnight visitors and all day-trippers, who account for a large share of total visitors, will have arrived that day. Visitor travel surveys take various approaches to addressing this challenge. The San Diego County Visitor Survey asks respondents to "report for either today or yesterday. Select the day you visited the most places in San Diego" (SANDAG Applied Research Division 2012). This solution may skew results towards more travel and will necessarily capture only a portion of a travel day. Another approach is to ask about anticipated travel. The San Antonio Regional Visitor Survey asks people who are only in San Antonio for the day to "please list all trips you have completed today plus any additional trips that you plan to make today" (ETC Institute 2008). This approach provides a full travel diary, but may not reflect trips that are actually taken nor accurate trip start and end times. (Interestingly, the San Antonio Regional Visitor Survey does not request any information on trip start or end times. This omission speeds surveying, but may not provide necessary information to transit agencies on when services need to be available.)

A third approach, which combines elements of the two discussed above, is to ask the visitor to identify an activity destination he or she visited and then ask about that trip in detail. The Portland Metro Visitor Travel Study, the only visitor travel survey aimed at transit demand, had respondents build a full one-day travel diary and then selected a single trip from that diary for a stated preference experiment regarding transit (Resource System Group 2010). Alternatively, a survey could identify specific trips based on respondents reporting visiting a destination of interest to the transit agency (e.g., a museum campus, airport, entertainment/business district, etc.) without first building the full trip diary. The survey could then explore one of these trips in more detail to identify travel times, modes, party size, etc. This method may collect the information of interest to the transit agency without reducing response rates by making the survey too burdensome on visitors.

\section{Stated Preference and Customer Satisfaction}

While household travel surveys rarely include stated preference or customer satisfaction questions, these are common components on transit surveys and should be considered as part of visitor travel surveys conducted by transit agencies.

Stated preference questions estimate respondent valuations for different service attributes-information essential to designing new transit options. Transit agencies seeking to lure more visitors commonly want to test valuations of entirely new services (e.g., 
circulators linking tourist destinations and downtowns, express rail services to air and seaports, extending rail lines to stadiums, reviving historic streetcars), changes in existing service levels (e.g., increasing runs in off-peak times, offering higher quality buses), and new fare options (e.g., multi-day visitor passes, airport station premiums, family fares, joint purchasing with event tickets, open fare payment systems, peak period pricing). Visitor travel surveys offer an excellent opportunity to explore these preferences among visitors; however, since such questions add length and complexity to the survey instrument, it is recommend that they be limited to a single policy concern per survey and be targeted to the relevant submarket. Such targeting is most easily accomplished in a survey delivered via computer, where the stated preference question can dynamically respond to a respondent's earlier answers. For example, a visitor who arrived by car would not receive the stated preference questions about rail service to the airport. Nonetheless, since a paper-based visitor travel survey is likely to be conducted at multiple sites, it is possible to tailor sections of the survey instrument to include stated preference sections pertinent to visitors physically intercepted at that site, such as adding questions about a downtown circulator on paper surveys conducted downtown.

Customer service questions, common to transit on-board surveys, are also very relevant to a visitor travel survey aimed at increasing transit ridership; however, their purpose is not to provide a snapshot of "how the agency is doing" but to identify key areas of improvement necessary to attract visitors. To effectively guide service improvements, surveys should ask about visitors' perceptions of local transit service, including the effectiveness of travel information and wayfinding materials, transparency of transit fare policy and ticket purchasing, and perceptions of transit cleanliness, safety, security and ease-ofuse. A particular concern of visitor travel surveys that is distinct from traditional transit on-board surveys is awareness of local transit options. For example, the Tahoe Summer Visitors Travel Survey specifically asks visitors, "Are you aware of public transportation in the Lake Tahoe Basin area?" This phrasing is likely too vague, as 47 percent of day visitors and 63 percent of long-term visitors reported being aware, although only 0.7 and 0.6 percent of day and long-term respondents, respectively, reported using transit on the day of the survey (NuStats 2004). It may make more sense to focus on specific services, as in an airport access survey that found that only half the out-of-towners accessing Chicago's O'Hare airport in 1990 were aware of the direct rail connection to the downtown that had opened six years earlier (Chicago Transit Authority 1990).

Transit agencies conducting visitor travel surveys should take advantage of the opportunity to explore not only travel behaviors, but also the attitudes and perceptions that undergird those behaviors. Stated preference and customer satisfaction questions address these needs, but should be included in a judicious and targeted manner to avoid making the survey administration unwieldy.

\section{Socio-Demographics}

As for any travel survey, demographic information is essential for characterizing the sample and understanding submarkets; however, in a visitor travel survey, demographic questions should go beyond standard queries (e.g., educational attainment, age, gender, household income, family size, ethnicity, etc.) to incorporate data that relates to the 
respondent as a visitor and as a potential transit user. For example, visitor home location can be used to target marketing materials or assess existing transit exposure, visitor native language and English proficiency levels can help transit agencies make decisions about translating user information, visitor driver's license availability and reported use of transit at home locations can inform models of potential transit use, and visitor access to technologies (credit cards, local Internet, smartphone service) can identify either avenues to or barriers blocking transit use.

\section{Visit Information}

The main addition to a visitor travel survey that is not present in a traditional travel survey is a section on the visit itself. Some of these questions are common on standard visitor surveys, but this base set needs to be augmented to incorporate data that are critical for understanding local travel. For example, visitor surveys typically request the length of the visit (either in days or in nights in the region, or both). Visit length likely correlates to travel decisions as visitors staying for longer periods may be more willing to rent a vehicle or learn about the local transit system or purchase a multiday transit pass; however, a visitor travel survey should also probe further to identify the date and time of entry and exit. This information yields additional insight into whether existing transit is even available to meet the needs of the arriving or departing visitor.

The visit section should inquire about the visit purpose to help categorize transit submarkets, such as time-sensitive business travelers or budget backpackers. Many visitors will have multiple purposes for their trip. A business traveler may stay at his or her destination through the weekend to visit family. Similarly, trip purposes may vary for people within a single traveling party. One member may be on a business trip, while another may be piggybacking on the free accommodation to tour the city. Effective survey design should consider a multiplicity of trip purposes with an accompanying hierarchy. For example, the Survey of International Air Travelers Departing the United States offers a list of 14 purposes and asks respondents to select one "main" purpose and as many "other" purposes as applicable (International Trade Administration 2012). The London Visitor Survey asks visitors who report coming to London for business purposes to further specify if they attended a conference, extended their trip for leisure, or engaged in leisure activities during their business trip. That survey also asks leisure travelers if shopping or a sporting event was an important motivator for the trip (TNS Travel and Tourism 2010).

The visit section should identify the long-distance travel modes that the respondent used to arrive at the region and, if relevant, the local travel modes used to arrive at the main destination within the region. Geocoding the "main destination" location is necessary to see if existing transit is available (or if future extensions are warranted). For overnight visitors, the "main destination" is likely a lodging location. The survey should further identify if that is a free or paid accommodation and, if it is the latter, to specify both the type of establishment and the cost paid per night. Lodging type and costs are useful data for categorizing visitors in statistical analysis.

The visit section needs to ask about the party size and composition. While party size is straightforward, describing the relationship of the travelers is complicated. The San Diego County Visitor Survey takes a simple approach to characterizing party composition by 
asking, "How many people traveled with you on this visit?" and then, "Of those, how many live in your household" (SANDAG Applied Research Division 2012). The Tahoe Summer Visitors Travel Survey takes a more detailed approach. The survey asks the respondent to identify up to 12 party members by age, gender, and relationship to the respondent. The relationship options include spouse/partner, son, daughter, mother, father, other relative, friend, and co-worker (NuStats 2004). This information can be useful for determining appropriate modes. For example, large families may generally favor private modes, such as taxis and rental cars, where there are no marginal costs for additional passengers, but could be receptive to a transit group rate. (Some surveys have everyone in the party respond separately [e.g., Carr Smith Corradino 2000; NuStats 2004], which is both more logistically challenging and more accurate.)

The visit component should inquire about vehicle availability. Many visitors will have access to their own vehicle, having driven to the visit location. Many visitors also will be provided access to a vehicle by local hosts either through a straight loan or through chauffeuring and shared activity participation. This availability may not be for all trips, but it may be for many of them. Many visitors also will rent vehicles either for one or more days from traditional agencies or for shorter periods through a pre-existing membership with a national carsharing service such as Zipcar and car2go. Transit agencies need to get a good sense of actual vehicle availability for each respondent to properly estimate the transit demand of visitor submarkets.

Finally, the visit section should inquire how the visitor gained knowledge for planning the trip (e.g., travel agency, Internet, guidebooks, etc.) and local navigation (e.g., printed maps, websites, mobile applications, concierge services, friends/family, etc.) to provide guidance on marketing transit services to visitors. Exploring visitor awareness and use of materials produced by the transit agency (e.g., on-line trip planners, visitor transit maps, etc.) is important to see if (and how) these aids are serving visitors. Surveys should also ask about visit frequency to the study region.

The discussion here on visit questions is designed to be comprehensive. Transit agencies should view this presentation as a menu from which to select the types of visit information most crucial to informing the policies under consideration, not a prescription. Since these data are also of particular interest to organizations that conduct more traditional visitor surveys, they may provide a way for transit agencies to engage outside partners in the visitor surveying effort leading to shared costs and other efficiencies.

\section{How Can a Visitor Travel Survey be Administered?}

Visitors introduce several administrative complications to a traditional travel surveying effort. These include problems of seasonality, local knowledge, interest in survey participation, and English proficiency.

\section{Seasonal Variation in Visitor Travel}

One complication, mentioned earlier, is that visitors' behaviors are likely to vary more than residents' behaviors over time. This issue was noted above regarding day-to-day variation, which might necessitate a multi-day survey to effectively capture the range and tradeoffs of travel behaviors. However, this issue also applies to seasons. Visitor flows 
demonstrate substantial seasonality. For example, in Chicago, 46 percent of all leisure trips are taken during the four summer months from June through September (D. K. Shifflet and Associates Ltd. 2012). This seasonal variation might affect the local travel of visitors if visitor activity participation is seasonal (e.g., attending outdoor concerts in the summer), if visitor travel behaviors are seasonal (e.g., preferring taxis to transit in the winter), or if the visitor composition is seasonal (e.g., families in summer, conventioneers in winter). Capturing the actual effects of seasonality on visitor travel might necessitate a survey administered at different times throughout the year. The Tahoe Regional Planning Agency conducted both a winter and a summer visitor travel survey to collect data on Lake Tahoe's two main tourist seasons (NuStats 2004). The Flagstaff Tourism Survey was administered one week per month for an entire year to provide a detailed breakdown of seasonal change (Arizona Hospitality Research \& Resource Center 2009). Alternatively, a region may be interested in visitors at a single season, as in South Florida where visitors were surveyed only during the winter (Carr Smith Corradino 2000). It will be important to avoid or at least account for any unusual events that might unusually alter visitor travel patterns during the survey administration. For example, surveying people during the Chicago Marathon or the Susan G. Komen Chicago 3-Day would result in findings of an abnormally high rate of pedestrian travel.

\section{Limited Visitor Knowledge of Local Geography}

A second complication is that many visitors lack local geographic knowledge and require an in-person surveyor to help identify locations. Two approaches are used to facilitate this geocoding: a low-tech, lower-cost approach of marking a physical map with zones (ETC Institute 2008; Simek 2009; Carr Smith Corradino 2000) and a high-tech, higher-cost approach, favored in more recent surveys, of using Web-connected devices with mapping programs (McCutchan 2013; Resource System Group 2010). Future surveys may use more technologically sophisticated methods such as wearable global positioning system (GPS) recorders or downloadable applications for visitors' smartphones. A challenge with these tracking technologies is that visitors would need to be contacted in advance to participate, which is unlikely to happen without virtual interception.

One possibility that might reduce the survey-side demands for technology might be to physically intercept visitors in the region to collect basic information, including email addresses, and then send out a link to an online portal for completing the travel behavior portion. It is not unreasonable to expect that some respondents could fill this travel information out online during their trip. One study of leisure visitors found that 46 percent used the Internet during their trip and that 31 percent brought smartphones and 10 percent brought computer tablets (Oftedal and Schneider 2012). It is not clear how successful such a "foot in the door" method would be. A similar design, in which respondents filled out an initial paper survey while on an airport shuttle and were given a postcard with an Internet address for the additional online survey, found only 18 percent of initial respondents followed up on-line (Sperry and Morgan 2011). Pushing the survey link directly to email inboxes may result in a higher response rate. It is important to note that moving the trip diary elements online does remove the benefit of interactions with a locally-knowledgeable surveyor and raises the geocoding burdens on respondents. 


\section{Limited Visitor Interest in Survey Participation}

This example touches on a third complication regarding visitor surveys, namely incentivizing participation. Participation by residents in household travel surveys or transit on-board surveys is thought to be in the respondent's self-interest, as his or her feedback will hopefully improve local transportation, serve as a slight and hopefully moderately interesting break from residents' routines, and appeal to a sense of civic duty. Yet, it still often requires a financial incentive. By contrast, visitors are unlikely to directly benefit from their survey participation, are already on a break from their routine (and therefore might view the survey as largely burdensome), and do not have strong civic commitments to the visited community-and, therefore, are more likely to need a financial incentive. The San Diego County Visitor Survey provided \$5 Starbucks gift cards to all 1,174 respondents (SANDAG Applied Research Division 2012), and the Tahoe Summer Visitors Travel Survey provided a small gift (valued at $\$ 4$ ) and a cash gratuity of a $\$ 2$ bill, somewhat of a novelty among U.S. currency (NuStats 2004). Despite the effectiveness and the accepted nature of financial incentives among surveying professionals, many transit agencies view rewards as a controversial use of public funds and are wary of offering them. Rewards also increase the cost of data collection.

Another (and complementary) approach is to exploit social norms of politeness by having an in-person interviewer. In addition to the local knowledge benefits noted above, interviewers create an implicit social contract that is harder to ignore. Both incentives and interviewers introduce surveying costs, but may be necessary. The Portland Metro Visitor Travel Study partnered with nine hotels to have check-in staff hand out postcards inviting guests to participate in the survey online. In the absence of either financial rewards or a paid interviewer, only 49 people responded to the 4,000 postcards that were distributed. Interestingly, 43 of these received their invitation at the same hotel, while no more than 2 responses came from any other hotel location (Resource System Group 2010). The survey report does not comment on why one hotel was more successful in engaging participants than others despite the same promotional training. One possibility, among many, is that hotel invested more of a human touch in encouraging participation.

\section{Visitor English Proficiency}

A final complication of visitor travel surveys is the potential linguistic variation among non-English speakers in the target population. All travel surveys need to be attuned to low English proficiency (LEP) populations; however, visitors may demonstrate an even higher variety of language than is typically found within a region. There are different ways to address this problem. The Oahu Visitor Survey hired Japanese-speaking interviewers (McCutchan 2013). This approach is effective, but only when a single foreign language is dominant among non-English speaking visitors. Great Britain's International Passenger Survey provides interviewers with self-completion cards in 13 foreign languages to hand out to non-English speakers. These cards do not replicate the full survey, but do capture much of the essential information (Office for National Statistics 2012). This less-costly approach ensures that visitors with a broader range of languages are incorporated, but at a lower level of detail. It should be possible to infer the likely linguistic needs of a visitor travel survey in advance based on available data on visitor countries of origin. This infor- 
mation can be used to appropriately design the survey while weighing tradeoffs between costs and coverage.

\section{Conclusion}

This research seeks to inform transit agencies regarding the key issues to conducting a successful visitor travel survey. This work identifies the overarching policy objectives of increasing ridership and revenue and considers the data collection needed to address those goals. This research holds that visitor travel surveys are important, but tricky. Substantial care needs to be devoted to defining and then intercepting visitors, many of whom never enter traditional visitor surveying venues of hotels and airports. Transit agencies will need to augment standard questions on travel behaviors to include preferences and perceptions and information on the visit itself to make sure the data collected yield responses that can guide public transportation policy. While visitors are difficult to survey, they may be very good for transit. This research provides key guidance for transit agencies looking to learn more about capitalizing on this promising market.

\section{Acknowledgments}

The author thanks, in alphabetical order, John G. Allen, Stacey Bricka, Rick Curry, Joel Freedman, Elizabeth Greene, Greg Spitz, Chris Simek, Wu Sun, Chris Tatham, and three anonymous reviewers for their help in preparing this paper, as well as the Regional Transportation Authority (RTA) in Chicago for supporting this research.

\section{References}

Arizona Hospitality Research \& Resource Center. 2009. Flagstaff Tourism Survey. Flagstaff, AZ: Arizona Office of Tourism.

Bergen, Kathy. 2012. Leisure travelers give state tourism a boost. Chicago Tribune, July 23, sec. Business.

Cardiff Research Center. 2010. Cardiff Visitor Survey 2010. Cardiff, UK.

Carr Smith Corradino. 2000. Southeast Florida regional travel characteristics study: Visitor travel survey plan and findings. Technical Report. Miami: Florida Department of Transportation.

Chicago Transit Authority. 1990. O'Hare Airport ground travel survey. Final Report SP 90-06. Chicago: Chicago Transit Authority.

City of Chicago. 2010. Chicago Office of Tourism: 2009 Statistical information. Chicago.

D. K. Shifflet and Associates Ltd. 2012. 2011 Illinois and Chicago charts and graphs.

ETC Institute. 2008. San Antonio regional visitor survey. Olathe, KS.

Future Focus Research. 2012. Cardiff visitor survey 2012. Cardiff, UK. 
Hourdos, John, and Stephen Titzow. 2011. Data Collection for the development of the next travel behavior inventory. Final report. Minneapolis, MN: Minnesota Traffic Observatory, University of Minnesota.

International Trade Administration. 2012. Survey of international air travelers departing the United States. Washington, DC: U.S. Department of Commerce.

Longwoods International. 2007. Portland Metro region: Regional analysis from the 2004/2006 Oregon visitor studies, September.

McCutchan, Ryan. 2013. Oahu visitor survey report. Austin, TX: NuStats.

Morpace International, Inc. 2000. Bay Area travel survey, Part 2-Retrieval. Oakland, CA: Metropolitan Transportation Commission.

NuStats. 2004. Summer visitors travel survey: Summary of results. Stateline, NV: Tahoe Regional Planning Agency.

Office for National Statistics. 2012. Travel trends, 2011. Newport, UK.

Oftedal, Andrew, and Ingrid Schneider. 2012. Twin Cities Metropolitan Area Summer Visitor Profile. Final Report. Metro Tourism Association.

Regional Transportation Authority. 2014. Regional Transportation Authority, Request for proposals, requisition \#2322 for Chicagoland visitors travel survey for a period of up to one year. Regional Transportation Authority.

Resource System Group. 2010. Portland Metro Visitor travel study. Survey report. White River Junction, VT.

SANDAG Applied Research Division. 2012. San Diego County survey of visitors. San Diego, CA: San Diego Association of Governments.

Simek, Chris. 2009. USVI visitor survey: Technical memorandum on survey methodology. Austin, TX: NuStats.

Sperry, B. R., and C.A. Morgan. 2011. Intercity passenger rail: Implications for urban, regional, and national mobility. Final report UTCM 11-10-75. College Station, TX: Texas Transportation Institute.

Statistics Canada. 2006. Canadian travel survey: Domestic travel, 2004. Ottawa.

TechnoMetrica. 2013. 2013 'Travel like a local' summer travel survey: A survey prepared for the American Public Transportation Association. Ramsey, NJ: American Public Transportation Association.

Tierney, Kevin, Steve Decker, Kimon Proussaloglou, Thomas Rossi, Earl Ruiter, Nancy McGuckin, Mark McCourt, Brenda Zhou, and Rob Sheldon. 2013. Chapter 19, Visitor surveys. In The On-Line Travel Survey Manual: A Dynamic Document for Transportation Professionals, 1-19. TRB Travel Survey Methods Committee (ABJ40). http://www. travelsurveymanual.org/Chapter-19.html.

TNS Travel and Tourism. 2010. London visitor survey: 2009 report, January-September. London: London Development Agency. 
Tourism Research Australia. 2012. Travel by Australians: September 2012 Quarterly results of the National Visitor Survey. Canberra: Department of Resources, Energy, and Tourism.

U.S. Travel Association. 2009. The economic impact of travel on Illinois counties 2008. Washington, DC.

\section{About the Author}

GreGory L. NeWmaRK (gnewmark@cnt.org) is a senior research analyst at the Center for Neighborhood Technology (CNT) and a lecturer at the Harris School of Public Policy Studies at the University of Chicago. 